\title{
Contemporary results after repair of partial and transitional atrioventricular septal defects
}

Carlos M. Mery, MD, MPH, ${ }^{\mathrm{a}}$ Rodrigo Zea-Vera, MD, ${ }^{\mathrm{a}}$ Martin A. Chacon-Portillo, MD, ${ }^{\mathrm{a}}$ Wei Zhang, PhD, ${ }^{\mathrm{b}}$ M. Scott Binder, BS, ${ }^{\mathrm{c}}$ William B. Kyle, MD, ${ }^{\mathrm{d}}$ Iki Adachi, MD, ${ }^{\mathrm{a}}$ Jeffrey S. Heinle, MD, ${ }^{\mathrm{a}}$ and

Charles D. Fraser, Jr, MD

\section{ABSTRACT}

Objective: The exact incidence and risk factors for reoperation in partial and transitional atrioventricular septal defects are unclear. The goal of this study was to assess risk factors for left atrioventricular valve and left ventricular outflow tract reoperation in partial and transitional atrioventricular septal defects.

Methods: All patients undergoing partial and transitional atrioventricular septal defects repair between 1995 and 2017 were reviewed. Patients were classified as infants ( $<1$ year), toddlers (1-3 years), children (3-17 years), and adults ( $\geq 18$ years). Survival and reoperation were assessed using log-rank test and Cox models for univariate and multivariable analyses, respectively.

Results: Overall, 265 patients underwent partial and transitional atrioventricular septal defects repair (partial: 177 [67\%]). Median age was 2 years. The cohort included 73 infants $(28 \%), 85$ toddlers $(32 \%)$, 94 children $(35 \%)$, and 13 adults $(5 \%)$. Trisomy 21 was present in 76 patients $(29 \%)$, and in 216 patients $(83 \%)$, the zone of apposition was completely closed. Perioperative mortality was $0.8 \%$. Complete heart block did not develop in any patients. Ten-year survival and freedom from reoperation were $98 \%$ and $81 \%$, respectively. On multivariable analysis, trisomy 21 (hazard ratio [HR], 0.16) and older age compared with infants (toddlers: HR, 0.35; children: HR, 0.25) were protective for any reoperation, whereas heterotaxy $(\mathrm{HR}, 3.43)$ was a risk factor. For left atrioventricular valve reoperation, toddlers (HR, 0.35), children (HR, 0.25), and trisomy 21 (HR, 0.16) remained protective, whereas left atrioventricular valve anomaly was a risk factor (HR, 2.61). Likewise, for left ventricular outflow tract reoperation, toddlers (HR, 0.24) and children (HR, 0.06) were protective.

Conclusions: Mortality after partial and transitional atrioventricular septal defects repair is minimal, yet reoperation for left atrioventricular valve disease and left ventricular outflow tract obstruction remains significant. Patients requiring repair during infancy are at higher risk of reoperation. (J Thorac Cardiovasc Surg 2019;157:1117-27)

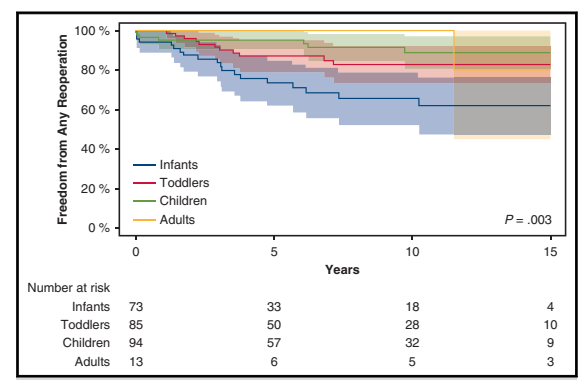

Freedom from any reoperation by age categories.

\section{Central Message}

Mortality after partial and transitional atrioventricular septal defect repair is low. Reoperation is not uncommon. Need for repair in infancy is associated with higher reoperation rates.

\section{Perspective}

Repair of partial and transitional atrioventricular septal defects is performed with low mortality, but reoperation remains concerning. The ideal timing of repair is unclear. Need for repair in infancy is a marker of higher risk of reoperation for any cause, left atrioventricular valve disease, and left ventricular outflow tract obstruction. Patients repaired during infancy require closer follow-up.

See Commentaries on pages 1128 and 1130 .

\footnotetext{
From the Divisions of a Congenital Heart Surgery and ${ }^{\mathrm{d}}$ Pediatric Cardiology, Texas Children's Hospital/Baylor College of Medicine, Houston, Tex; ${ }^{\mathrm{b}}$ Outcomes and Impact Service, Texas Children's Hospital, Houston, Tex; and ${ }^{c}$ Eastern Virginia Medical School, Norfolk, Va.

Institutional Review Board approval: H-39789 (June 26, 2017).

Read at the 98th Annual Meeting of The American Association for Thoracic Surgery, San Diego, California, April 28-May 1, 2018.

Received for publication May 1, 2018; revisions received Sept 28, 2018; accepted for publication Oct 12, 2018

Address for reprints: Carlos M. Mery, MD, MPH, Congenital Heart Surgery, Texas Children's Hospital, 6621 Fannin St, MC19345H, Houston, TX 77030 (E-mail: cmmery@gmail.com).

$0022-5223 / \$ 36.00$

Copyright (C) 2018 Published by Elsevier Inc. on behalf of The American Association for Thoracic Surgery

https://doi.org/10.1016/j.jtcvs.2018.10.154
}

Partial and transitional atrioventricular septal defects (P/TAVSDs) are endocardial cushion defects with none or limited ventricular shunting, and as such, they usually become symptomatic later in life. Thereby, in contrast to

Uf Scanning this QR code will
take you to the article title
page to access supplementary
information. To view the
AATS Annual Meeting Web-
cast, see the URL next to the
webcast thumbnail.




$$
\begin{array}{ll}
\text { Abbreviations and Acronyms } \\
\text { CI } & =\text { confidence interval } \\
\text { ASD } & =\text { atrial septal defect } \\
\text { AVSD } & =\text { atrioventricular septal defect } \\
\text { HR } & =\text { hazard ratio } \\
\text { LAVV } & =\text { left atrioventricular valve } \\
\text { LVOT } & =\text { left ventricular outflow tract } \\
\text { PPM } & =\text { permanent pacemaker } \\
\text { P/TAVSD } & =\text { partial and transitional atrioventricular } \\
& \text { septal defect } \\
\text { T21 } & =\text { trisomy } 21 \\
\text { VSD } & =\text { ventricular septal defect }
\end{array}
$$

complete atrioventricular septal defect (AVSD), which is commonly repaired between 3 and 6 months of age, ${ }^{1}$ P/TAVSD is commonly repaired later in life. ${ }^{2}$ Currently, perioperative mortality is consistently reported to be approximately $1 \%$, with a range from $0 \%$ to $4.5 \% .^{3-11}$

Reoperation, commonly due to left atrioventricular valve (LAVV) disease, is the most common cause of morbidity, with a reported 10-year incidence between $15 \%$ and $20 \%$. 3,5,9 LAVV regurgitation, LAVV anatomy, and associated cardiovascular anomalies have been reported as risk factors for reoperation. ${ }^{3,6}$ Repair during infancy has been reported to carry high mortality and morbidity, ${ }^{12,13}$ yet the ideal age at repair continues to be a matter of debate. $^{4,5,7,9}$ Several anatomic characteristics place patients with P/TAVSD at risk for left ventricular outflow tract (LVOT) obstruction ${ }^{14-16}$; therefore, as much as $5 \%$ to $10 \%$ of patients will develop significant LVOT obstruction during follow-up. ${ }^{17,18}$

The risk factors for reoperation and the ideal age at repair remain unclear. The goal of this study was to determine the current expectations and risk factors for reoperation after surgical repair of P/TAVSD by reviewing our 22-year experience.

\section{MATERIALS AND METHODS}

All patients undergoing repair of P/TAVSD at Texas Children's Hospital between June 1995 and January 2017 were included. Patients with heterotaxy, other cardiac malformations, and genetic syndromes were also included. This study was approved by the Institutional Review Board at Baylor College of Medicine, and informed consent was waived.

All demographic and clinical data, including interventions, complications, and hospital course, were collected by retrospective review of all medical records. Follow-up was obtained by a combination of clinic notes review and telephone interviews of patients, families, and referring physicians.

The diagnosis of partial AVSD was made according to Society of Thoracic Surgeons guidelines, that is, a primum atrial septal defect (ASD) and a cleft LAVV. A transitional AVSD was defined as having a primum ASD and a pressure-restrictive inlet ventricular septal defect (VSD). ${ }^{6,19,20}$

\section{Echocardiographic Measurements}

Reports were reviewed for the last preoperative transthoracic echocardiography, the postoperative transesophageal echocardiography, the

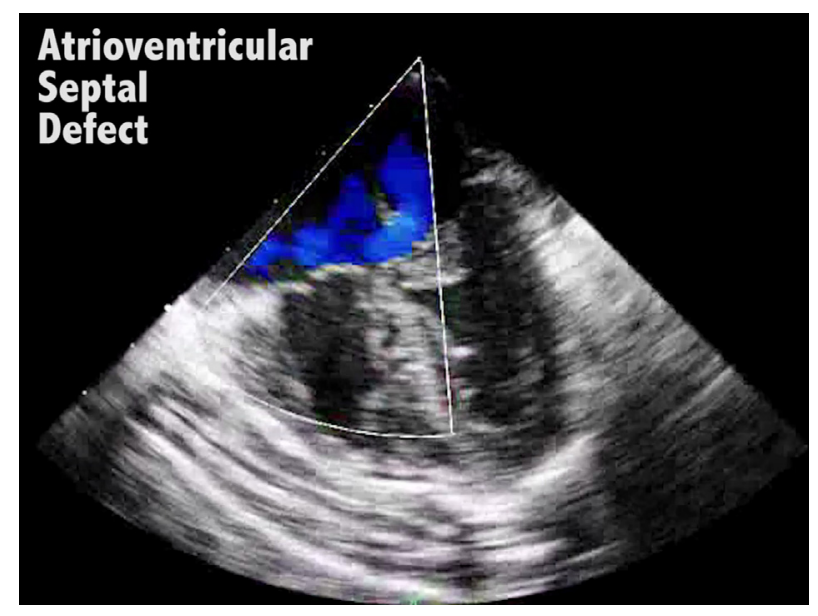

VIDEO 1. Repair of a transitional atrioventricular septal defect using the modified single patch technique. Video available at: https://www.jtcvs.org/ article/S0022-5223(18)33146-5/fulltext.

discharge transthoracic echocardiography, and the last recorded echocardiography.

Because standard quantification methods such as regurgitant fraction and regurgitant volume are not standardized and quantification is challenging in the presence of a noncircular orifice and eccentric jets, LAVV regurgitation is routinely classified on the basis of jet width and pulmonary venous inflow pattern. ${ }^{21}$ An LVOT maximum instantaneous gradient of $20 \mathrm{~mm} \mathrm{Hg}$ or more by spectral Doppler was considered to be significant. For consistency, when 2 nearby studies were discrepant, the study performed closest to the surgery was recorded.

\section{Surgical Technique}

Our center will commonly offer surgery for asymptomatic patients aged 3 to 5 years. In patients repaired before 3 years of age, the preoperative cardiology note, surgical consultation, and operative note were reviewed to determine surgical indication.

We have favored an autologous pericardial patch closure of the primum ASD. In the setting of a transitional AVSD, the VSD is closed primarily, using the modified single patch (Australian) technique ${ }^{22,23}$ or, rarely, using a second patch (Video 1). The zone of apposition of the LAVVor "mitral cleft" is closed primarily except for those cases in which closure would lead to LAVV stenosis.

\section{Risk Factors}

Patients were classified according to age at repair as infants $(<1$ year), toddlers ( $\geq 1$ year to $<3$ years), children ( $\geq 3$ years to $<18$ years), or adults ( $\geq 18$ years). Age was also assessed as a continuous variable. Given the nonlinear relationship to the outcome, a variable $\left(\mathrm{age}^{2}\right)$ was included in the model to better study the effect of age. Because the results were largely unchanged from those with categoric age, and the easier interpretation and clinical applicability of age groups, the main analysis uses age categories. The analysis with age as a continuous variable is shown in the Appendix (Table E1 and Figure E1).

Two eras were defined according to year of surgery: old era (1995-2005) and recent era (2006-2017). LAVV anomaly was defined as the presence of a double orifice LAVV, single papillary muscle, or significantly deficient left lateral leaflet, ${ }^{24}$ as reported by the surgeon. Genetic syndromes were analyzed as a 3-level categoric variable: no syndrome, trisomy 21 (T21), or other genetic syndromes.

Risk factors assessed for significance included age category, partial versus transitional AVSD, genetic syndromes, heterotaxy, second bypass run, preoperative congestive heart failure, LAVV anomaly, preoperative 
moderate or severe LAVV regurgitation, and preoperative significant LVOT obstruction.

Outcomes included perioperative (before discharge or within 30 days from the procedure) mortality and reoperation. Long-term outcomes included mortality, reoperation due to any cause, reoperation for LAVV disease (regurgitation or stenosis), and reoperation for LVOT obstruction.

\section{Statistical Analysis}

Continuous variables are summarized as means (standard deviations) or medians (ranges). Comparisons were performed using the Student $t$ test or the Wilcoxon rank-sum, as appropriate. Categoric variables are reported as frequency (percentage) and compared with the Fisher exact test or the chisquare test, as appropriate.

Kaplan-Meier estimates were used to assess time-dependent outcomes since time of surgery. For survival, all patients were included and censored at the last time they were seen alive. For any reoperation, LAVV reoperation, and LVOT reoperation, patients were censored at the time of last follow-up or death.

Univariate analysis was performed using the log-rank test. Variables with a $P$ value less than .10 in the univariate analysis were included in a Cox regression model. Results of the multivariable analysis are reported as hazard ratios (HRs) and $95 \%$ confidence intervals (CIs).

Given the possible bias based on heterogeneous follow-up time and patients lost to follow-up, we performed 2 sensitivity analyses. In the first, we excluded all patients with less than 3 years of follow-up. For the second, we excluded those who had not been seen in the last 2 years before the study ended (lost to follow-up). All the analyses were performed again for both cases, and results were largely unchanged.

Statistical analysis was performed using the survival package for R Statistical Software Version 3.3.1 (Foundation for Statistical Computing, Vienna, Austria).

TABLE 1. Baseline demographics by groups

\begin{tabular}{|c|c|c|c|c|}
\hline Variable & Partial AVSD N $=177$ & Transitional AVSD $\mathbf{N}=\mathbf{8 8}$ & $P$ value & Total $N=265$ \\
\hline Old era (1995-2005) & $87(49.2 \%)$ & $41(46.6 \%)$ & .903 & $128(48.3 \%)$ \\
\hline Recent era (2006-2017) & $90(50.8 \%)$ & $47(43.3 \%)$ & & $137(41.7 \%)$ \\
\hline Age & $3 \mathrm{y}(8 \mathrm{~d}$ to $55 \mathrm{y})$ & 1 y (7 d-32 y) & $<.001$ & $2 \mathrm{y}(7 \mathrm{~d}$ to $55 \mathrm{y})$ \\
\hline Weight (kg) & $13(2-124)$ & $9(3-69)$ & $<.001$ & $11(2-124)$ \\
\hline Female & $100(56.5 \%)$ & $51(57.9 \%)$ & .895 & $151(56.9 \%)$ \\
\hline Infants & $32(18.1 \%)$ & $41(46.6 \%)$ & & $73(27.5 \%)$ \\
\hline Toddlers & $61(34.5 \%)$ & $24(27.3 \%)$ & $<.001$ & $85(32.1 \%)$ \\
\hline Children & $73(41.2 \%)$ & $21(23.9 \%)$ & & $94(35.5 \%)$ \\
\hline Adults & $11(6.2 \%)$ & $2(2.3 \%)$ & & $13(4.9 \%)$ \\
\hline No genetic syndrome & $127(71.8 \%)$ & $48(54.5 \%)$ & & $175(66.0 \%)$ \\
\hline Trisomy 21 & $40(22.6 \%)$ & $36(40.9 \%)$ & .009 & $76(28.7 \%)$ \\
\hline Other genetic syndromes* & $10(5.6 \%)$ & $4(4.5 \%)$ & & $14(5.3 \%)$ \\
\hline Heterotaxy & $7(4.0 \%)$ & $2(2.3 \%)$ & .722 & $9(3.4 \%)$ \\
\hline Outpatient & $166(93.8 \%)$ & $79(89.8 \%)$ & .323 & $245(92.5 \%)$ \\
\hline Congestive heart failure & $64(36.2 \%)$ & $38(43.2 \%)$ & .286 & $102(38.5 \%)$ \\
\hline Preoperative LAVV regurgitation moderate or more & $64(36.2 \%)$ & $26(29.5 \%)$ & .336 & $90(33.8 \%)$ \\
\hline Preoperative RAVV regurgitation moderate or more & $31(17.5 \%)$ & $21(23.9 \%)$ & .251 & $52(19.5 \%)$ \\
\hline Significant LVOTO & $4(2.3 \%)$ & 0 & .305 & $4(1.5 \%)$ \\
\hline LAVV anomaly & $31(17.5 \%)$ & $11(12.5 \%)$ & .372 & $42(15.8 \%)$ \\
\hline Concomitant cardiac anomalies & $101(57.1 \%)$ & $64(72.7 \%)$ & .015 & $165(62.3 \%)$ \\
\hline ASD/PFO non-primum & $78(44.1 \%)$ & $58(65.9 \%)$ & .001 & $136(51.3 \%)$ \\
\hline VSD noninlet & $1(0.6 \%)$ & $3(3.4 \%)$ & .108 & $4(1.5 \%)$ \\
\hline PDA & $32(18.1 \%)$ & $29(33.0 \%)$ & .008 & $61(23.0 \%)$ \\
\hline Juxtaductal aortic coarctation & $2(1.1 \%)$ & $1(1.1 \%)$ & .999 & $3(1.1 \%)$ \\
\hline Left SVC & $7(4.0 \%)$ & 0 & .099 & $7(2.6 \%)$ \\
\hline Anomalous systemic veins $\dagger$ & $6(3.4 \%)$ & $1(1.1 \%)$ & .431 & $7(2.6 \%)$ \\
\hline PAPVR & $3(1.7 \%)$ & 0 & .553 & $3(1.1 \%)$ \\
\hline Other & $6(3.4 \%)$ & $2(2.3 \%)$ & .999 & $8(3.0 \%)$ \\
\hline
\end{tabular}

Data are reported as median (range) or frequency (\%). AVSD, Atrioventricular septal defect; $L A V V$, left atrioventricular valve; RAVV, right atrioventricular valve; $L V O T O$, left ventricular outflow tract obstruction; $A S D$, atrial septal defect; $P F O$, patent foramen ovale; $V S D$, ventricular septal defect; $P D A$, patent ductus arteriosus; SVC, superior vena cava; PAPVR, partial anomalous pulmonary venous return. *CHARGE (3), Ellis-Van Creveld (3), Noonan's (3), Aarskog (1), Carnitine biosynthesis defect (1), Coffin-Siris (1), Holt-Oram (1), Wolf-Hirschhorn (1). †Interrupted IVC (5), probable hemi azygous to coronary sinus connection (1), absent portal vein (1). †Pulmonary valve stenosis (4), aortic arch hypoplasia (1), aberrant right subclavian (1), complete occlusion of the descending aorta with bilateral iliac reconstruction by collaterals (1), vascular ring (1). 


\section{RESULTS}

Overall, 177 patients $(66.8 \%)$ with a partial and 88 patients $(33.2 \%)$ with a transitional AVSD underwent repair, for a total of 265 patients included in the cohort. Median age at repair was 2.2 years ( 7.0 days to 54.7 years), and median weight was $11(2-124) \mathrm{kg}$. Patients in the transitional AVSD group were younger and had a higher incidence of T21 (Table 1).

The cohort included 73 infants $(27.5 \%)$ (including 6 neonates), 85 toddlers (32.1\%), 94 children $(35.5 \%)$, and 13 adults $(4.9 \%)$. The surgical indications for infants and toddlers $(\mathrm{n}=158)$ were congestive heart failure in $85(53.7 \%)$; moderate or severe LAVV regurgitation in $28(17.7 \%)$; right heart enlargement or radiographic signs of overcirculation in $29(18.4 \%)$; social reasons, family, or clinician preference in $11(7.0 \%)$; LVOT obstruction in $2(1.3 \%)$; and others (ie, new aortic insufficiency, left pulmonary artery compression, extracardiac respiratory disease) in 3 patients $(1.9 \%)$.

Seven patients $(2.6 \%)$ had cardiovascular procedures before complete repair. These included 2 Wolf-ParkinsonWhite syndrome ablations; 2 permanent pacemaker (PPM) placements due to congenital complete heart block; 2 patent ductus arteriosus closures, 1 of them with a concomitant pulmonary artery band; and 1 aortic balloon valvuloplasty.

Preoperatively, 90 patients $(33.9 \%)$ had moderate or severe LAVV regurgitation, 61 of whom already had moderate or severe LAVV regurgitation at presentation to our center. There were no differences in preoperative LAVV regurgitation between age categories $(P=.77)$ or partial versus transitional AVSD $(P=.36)$. An LAVV anomaly was seen in 42 patients $(15.8 \%)$. The individual LAVV anomalies were 26 double orifice LAVVs, 10 single left papillary muscles, and 10 deficient left lateral leaflets.

The LAVV zone of apposition was closed completely in 216 patients $(81.5 \%)$, was closed partially in 40 patients $(15.1 \%)$, and was left open in 9 patients $(3.4 \%)$. The reasons for leaving the cleft completely open included a small LAVV in 5, a tiny or nonexistent LAVV cleft in 2, and very delicate LAVV tissue in 2 cases.

Among the 88 patients with a transitional AVSD, the VSD was closed primarily in 69 patients $(78.4 \%)$ by a modified single patch technique in $17(19.3 \%)$ and using a small pericardial patch in 2 patients $(2.3 \%)$. The ASD was partially closed in 2 patients $(0.8 \%)$ because of concern for postoperative pulmonary hypertension.

Three patients $(1.1 \%)$ underwent a concomitant aortic arch repair, and 7 patients $(2.6 \%)$ underwent a concomitant subaortic resection. A second bypass run was required in 11 patients $(4.2 \%)$; the indications included LAVV regurgitation in 4 patients, LAVV stenosis in 3 patients, multiple residual VSDs in 1 patient, debris in the ASD patch in 1 patient, and hemodynamic instability in 2 patients. All of the residual defects and hemodynamic instability were corrected on the second bypass run.

\section{Perioperative Outcomes}

Two patients $(0.8 \%)$ died perioperatively. The first was a 2-month-old female patient born with dysmorphic features, small left-sided structures, aortic stenosis, vascular ring, and a partial AVSD who had remained hospitalized since

TABLE 2. Perioperative outcomes and complications

\begin{tabular}{|c|c|c|c|c|}
\hline Variable & Partial AVSD N $=177$ & Transitional AVSD $\mathbf{N}=\mathbf{8 8}$ & $P$ value & Total $N=265$ \\
\hline CPB time (min) & $108(58-273)$ & $137(63-370)$ & $<.001$ & $118(58-370)$ \\
\hline AXC time (min) & $75(25-175)$ & $100(37-285)$ & $<.001$ & $80(25-285)$ \\
\hline Second bypass run & $3(1.7 \%)$ & $8(9.1 \%)$ & .007 & $11(4.2 \%)$ \\
\hline ICU LOS (d) & $2(1-24)$ & $2(1-31)$ & .108 & $2(1-31)$ \\
\hline $\operatorname{LOS}(d)$ & $5(3-67)$ & $5(2-253)$ & .001 & $5(2-253)$ \\
\hline Perioperative mortality & $1(0.6 \%)$ & $1(1.1 \%)$ & .999 & $2(0.8 \%)$ \\
\hline Perioperative reoperation & $2(1.1 \%)$ & $3(3.4 \%)$ & .337 & $5(1.9 \%)$ \\
\hline ECMO placement & 0 & $1(1.1 \%)$ & .332 & $1(0.4 \%)$ \\
\hline Infection & $7(3.9 \%)$ & $2(2.3 \%)$ & .722 & $9(3.4 \%)$ \\
\hline Pericardial effusion & $5(2.8 \%)$ & 0 & .174 & $5(1.9 \%)$ \\
\hline Chylothorax & 0 & $4(4.5 \%)$ & .012 & $4(1.5 \%)$ \\
\hline Arrhythmia medically treated & $2(1.1 \%)$ & $1(1.1 \%)$ & .999 & $3(1.1 \%)$ \\
\hline Arrhythmia temporary pacing & $2(1.1 \%)$ & $3(3.4 \%)$ & .337 & $5(1.9 \%)$ \\
\hline Complete heart block & 0 & 0 & & 0 \\
\hline
\end{tabular}

Data are reported as median (range) or frequency (\%). AVSD, Atrioventricular septal defect; $C P B$, cardiopulmonary bypass; $A X C$, Aortic crossclamp; ICU, intensive care unit; $L O S$, length of stay; $E C M O$, extracorporeal membrane oxygenator. 
birth. After an unsuccessful balloon valvuloplasty, she had a partial AVSD repair and division of the vascular ring at 2 months of age. She developed pneumonia and was found to have moderate to severe pulmonary vein stenosis in 3 of the 4 veins, not deemed amenable to surgical or interventional management. She died of pulmonary hypertension on postoperative day 42 .

The second patient was a 5-month-old male with a transitional AVSD, left atrial isomerism, intestinal malrotation, and biliary atresia. He underwent a Kasai and Ladd procedure at 2 months of age that failed ensuing severe ascites and respiratory failure. A repair was undertaken to make him a liver transplant candidate. Postoperatively, he required pacing for 1 week, and a PPM was implanted because of sick sinus syndrome. He died of respiratory failure and multiple infectious episodes on postoperative day 20.

Table 2 describes the perioperative outcomes and complications. The indications for the 5 patients $(1.9 \%)$ reoperated perioperatively were 3 severe LAVV regurgitation, 1 left superior vena cava partial occlusion, and 1 sick sinus syndrome (described earlier). Five patients $(1.9 \%$ ) required perioperative pacing; indications included transient seconddegree atrioventricular block in 1 , junctional ectopic tachycardia in 2 , and sinus bradycardia in the remaining 2 patients. One of these patients required extracorporeal membrane oxygenator for 3 days because of hemodynamic decompensation and remained on antiarrhythmic therapy at discharge, which was eventually weaned during follow-up. No patient developed complete heart block.

Postoperatively, 9 patients $(3.4 \%)$ had moderate or severe LAVV regurgitation on transesophageal echocardiography. Five patients had the zone of apposition left partially or completely open because of the risk of stenosis, and in 4 patients, the surgeon thought further repair would not be feasible. At discharge, 36 patients (13.6\%) had moderate or severe LAVV regurgitation, and none had significant LVOT obstruction or LAVV stenosis at discharge. One patient had a nonintentional residual ASD, and 4 patients had a residual VSD (1 near the patch margin and 3 muscular). One was closed during a reintervention for LAVV repair, and all others were closed spontaneously.

\section{Long-Term Outcomes}

Median follow-up for the entire cohort was 7 years (3 days to 21 years). There were 3 late mortalities: 1 in the partial AVSD group at 1.7 months and 2 in the transitional AVSD group at 0.9 and 3.3 years. Overall survival was $97.7 \%(95 \% \mathrm{CI}, 95.8-99.7)$ at 5,10 , and 15 years. When comparing infants against all other age categories grouped together, there was a statistically significant difference in survival $(P=.01)$; likewise, the presence of heterotaxy $(P=.03)$ was associated with increased mortality. Complete closure of the zone of apposition compared with those with partial/none closure of the zone of apposition $(P=.01)$ was found to be a protective factor.

During follow-up, 29 patients $(11.0 \%), 7$ patients $(2.7 \%), 1$ patient $(0.4 \%)$, and 1 patient $(0.4 \%)$ underwent $1,2,3$, and 4 reoperations, respectively, for a total of 50 reoperations in 38 patients $(14.5 \%)$. Median time to any reoperation was 3 years ( 1 day to 12 years). The individual procedures included LAVV repairs $(\mathrm{n}=31 / 50,62 \%)$, subaortic membrane resection $(\mathrm{n}=20 / 50,40 \%)$, LAVV replacement $(n=6 / 50,12 \%)$, PPM placement $(n=3 / 50$, $6 \%$ ), and others $(\mathrm{n}=7 / 50,14 \%$ ) (ie, Maze procedure, aortic root replacement, right atrioventricular valve repair, ASD patch dehiscence repair, residual VSD closure, left superior vena cava revision, and ascending aorta and arch replacement). The $6 \mathrm{LAVV}$ replacements were performed in 5 patients using a St Jude (Abbott Laboratories, Lake Bluff, Ill) mechanical valve. The 2 late PPM placements were due to sick sinus syndrome in the setting of left isomerism and Wolf-Hirschhorn syndrome.

The freedom from any reoperation at 5,10 , and 15 years from the date of initial repair was $86.6 \%(95 \% \mathrm{CI}, 82.1$ 91.4 ), $80.8 \%$ (95\% CI, 75.2-86.9), and $78.6 \%$ (95\% CI, 72.4-85.3), respectively (Figure 1). After univariate analysis, age category $(P=.003)$, genetic syndrome $(P=.014)$, heterotaxy $(P<.001)$, congestive heart failure $(P=.050)$, and a LAVV anomaly $(P=.024)$ were included in the multivariable model (Table E2). After controlling for confounders, toddlers (HR, 0.30) and children (HR, 0.20) were protective factors compared with infants. Likewise, T21 (HR, 0.18) was a protective factor compared with patients without genetic syndromes, and heterotaxy was a risk factor (HR, 3.43) (Table 3).

Twenty-eight patients $(10.6 \%)$ had at least 1 LAVV reoperation. The specific causes for LAVV regurgitation in 10 patients with an abnormal LAVV were 6 regurgitations through a zone of apposition intentionally left partially open, 1 through a secondary orifice, 1 from annulus dilation, 1 dehiscence of the zone of apposition, and 1 because of a dysplastic valve with short chordae. The second most common cause of regurgitation was dehiscence of the zone of apposition closure in 9, followed by a dysplastic valve (ie, short chordae, multiple accessory clefts, and severely thickened edges) in 2. Other causes included dehiscence of an Alfieri stitch $(\mathrm{n}=1)$, zone of apposition partially closed previously $(\mathrm{n}=1)$, LAVV fenestration between sutures $(\mathrm{n}=1)$, and mild LAVV regurgitation but need for reintervention due to LVOT obstruction $(\mathrm{n}=3)$.

The freedom from LAVV reoperation at 5,10 , and 15 years was $89.3 \%$ (95\% CI, 85.1-93.6), 85.6\% (95\% CI, 80.5-90.9), 


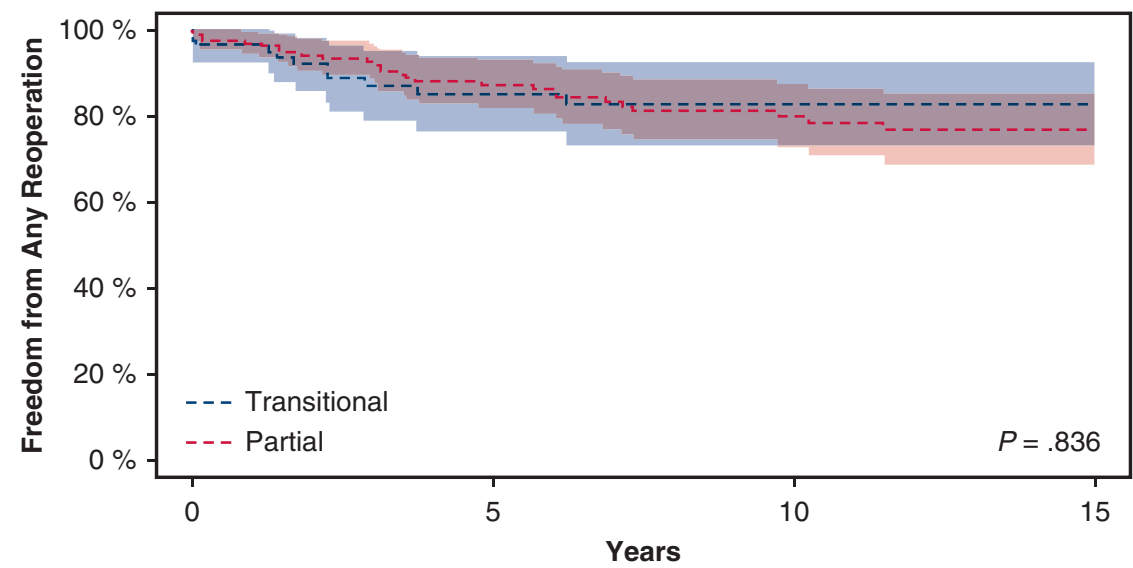

Number at risk

$\begin{array}{lllll}\text { Transitional } & 88 & 44 & 25 & 7\end{array}$

$\begin{array}{llll}\text { Partial } 177 & 102 & 58 & 19\end{array}$

A

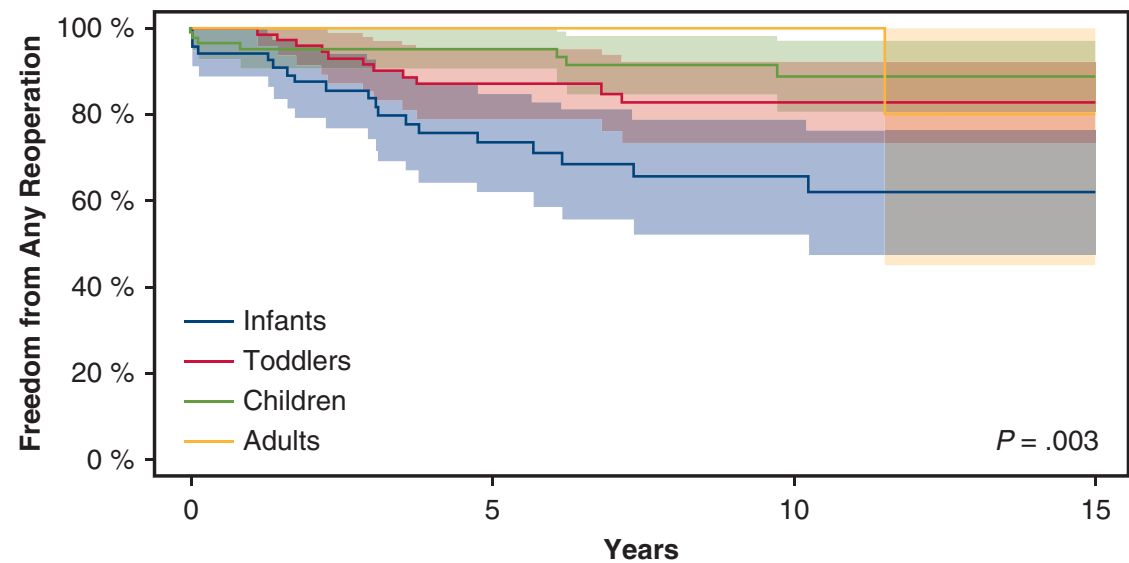

Number at risk

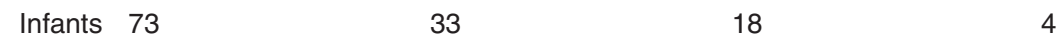

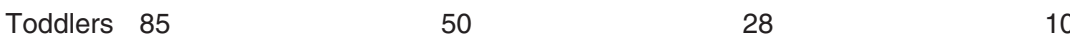

$\begin{array}{lllll}\text { Children } & 94 & 57 & 32 & 9\end{array}$

B

Adults 13

5

3

FIGURE 1. Freedom from any reoperation by P/TAVSD (A) and age categories (B).

and $84.3 \%$ (95\% CI, 78.9-90.2), respectively (Figure 2). Age category $(P=.053)$, genetic syndromes $(P=.035)$, congestive heart failure $(P=.048)$, and a LAVV anomaly $(P=.004)$ were chosen to be included in the multivariable analysis (Table E3). After controlling for confounders, toddlers (HR, 0.35) and children (HR, 0.25) compared with infants, and T21 (HR, 0.16) remained significant protective factors. A LAVV anomaly was found to be a risk factor for LAVV reoperation with an HR of 2.61 (Table 3 ).

Overall, 14 patients $(5.3 \%)$ required an LVOT reoperation. The freedom from LVOT reoperation at 5, 10, and
15 years was 94.2\% (95\% CI, 90.9-97.6), 92.8\% (95\% CI, 89.1-96.7), and 91.8\% (95\% CI, 87.6-96.1), respectively (Figure 3). Median time to LVOT reoperation was 3.3 years (1.4-10.2 years); $79 \%$ occurred in the first 5 years of surgery, and in all cases a discrete subaortic membrane was present at reoperation, with additional tunnel-type obstruction in 1 patient. On univariate analysis, age category $(P=.009)$, partial versus transitional AVSD $(P=.055)$, and preoperative significant LVOT obstruction $(P=.011)$ were selected for inclusion in the model (Table E4). After controlling for confounders, toddlers 
TABLE 3. Multivariable analysis for any reoperation $(\mathrm{N}=38)$, left atrioventricular valve reoperation $(N=28)$, and left ventricular outflow tract reoperation $(\mathrm{N}=14)$

\begin{tabular}{|c|c|c|}
\hline Covariate & HR $(95 \%$ CI $)$ & $P$ value \\
\hline \multicolumn{3}{|l|}{ Any reoperation } \\
\hline Infant & Reference & \\
\hline Toddler* & $0.30(0.14-0.65)$ & .002 \\
\hline Children* & $0.20(0.08-0.54)$ & .001 \\
\hline Adult & $0.30(0.04-2.34)$ & .248 \\
\hline No genetic syndrome & Reference & \\
\hline Trisomy $21 *$ & $0.18(0.05-0.60)$ & .005 \\
\hline Other genetic syndromes & $1.90(0.56-6.48)$ & .304 \\
\hline Heterotaxy* & $3.45(1.27-9.37)$ & .015 \\
\hline Congestive heart failure & $0.93(0.44-1.95)$ & .844 \\
\hline LAVV anomaly & $2.04(0.97-4.25)$ & .059 \\
\hline \multicolumn{3}{|l|}{ LAVV reoperation } \\
\hline Infant & Reference & \\
\hline Toddler* & $0.36(0.15-0.86)$ & .022 \\
\hline Children* & $0.25(0.08-0.76)$ & .015 \\
\hline Adult & $0.50(0.06-4.07)$ & .515 \\
\hline No genetic syndrome & Reference & \\
\hline Trisomy $21^{*}$ & $0.15(0.04-0.67)$ & .012 \\
\hline Other genetic syndromes & $1.57(0.36-6.89)$ & .550 \\
\hline Congestive heart failure & $1.31(0.57-3.00)$ & .524 \\
\hline LAVV anomaly* & $2.58(1.15-5.83)$ & .022 \\
\hline \multicolumn{3}{|l|}{ LVOT reoperation } \\
\hline Infant & Reference & \\
\hline Toddler* & $0.24(0.07-0.81)$ & .021 \\
\hline Children* & $0.06(0.01-0.51)$ & .009 \\
\hline Adult & 0.00 (0.00-Inf.) & .998 \\
\hline Transitional AVSD & Reference & \\
\hline Partial AVSD* & $8.32(1.07-64.46)$ & .043 \\
\hline $\begin{array}{l}\text { Preoperative significant } \\
\text { LVOT obstruction }\end{array}$ & $5.99(0.72-49.85)$ & .098 \\
\hline
\end{tabular}

C-statistic for any reoperation: 0.77 (SE: 0.05), LAVV reoperation: 0.77 (SE: 0.06), and LVOT reoperation: 0.82 (SE: 0.08 ). $H R$, hazard ratio; $C I$, confidence interval; $L A V V$, left atrioventricular valve; $L V O T$, left ventricular outflow tract; $A V S D$, Atrioventricular septal defect. *Statistically significant.

(HR, 0.24) and children (HR, 0.06) had lower LVOT reintervention than infants, and partial AVSDs had an increased incidence compared with transitional AVSDs (HR, 8.32).

When analyzing the infant group separately $(\mathrm{n}=72)$, 10-year survival was $93.4 \%$ (95\% CI, 87.2-99.7), 10-year freedom from any reoperation was $65.5 \%(95 \% \mathrm{CI}$, 53.4-80.5) (Figure 1, B), 10-year freedom from LAVV reoperation was $76.1 \%(95 \% \mathrm{CI}, 65.4-88.6)$ (Figure 2, $B)$, and 10-year freedom from LVOT reoperation was 83.5\% (95\% CI, 73.5-94.8) (Figure 3, B).

\section{DISCUSSION}

We present one of the largest single-center, contemporary, cohorts analyzing outcomes after P/TAVSD repair. Overall, we found an operative mortality of $0.8 \%$ and a 10 -year survival of $98 \%$. However, despite the excellent survival, the 10-year incidence of reoperation and, more specifically, LAVV reoperation remains high at $19.2 \%$. We found that patients requiring surgery during infancy were at a higher risk of reoperation on multivariable analysis.

Two patients $(0.8 \%)$ died perioperatively. As such, our study supports the continued decrease in mortality found in some of the recent studies. ${ }^{4,6,7,9}$ Buratto and colleagues $^{8}$ found a statistically significant $(P=.04)$ decrease in survival when comparing infants to children older than 1-year-old. Our results support these findings.

The $81 \%$ 10-year freedom from reintervention in the current cohort is comparable to that previously reported. $^{3,5,9,10,25}$ Regarding the timing of repair, Minich and colleagues ${ }^{7}$ found an $89 \%(8 / 9)$ incidence of LAVV regurgitation at 6 months in children 4 to 7 years old, significantly higher than the $22 \%(11 / 50)$ in those repaired between 0 and 4 or after 7 years of age. They concluded that repair in children at 4 years or older increased the incidence of LAVV regurgitation at 6 months postoperatively.

In 86 patients repaired at a median age of 1.5 years, Devlin and colleagues ${ }^{4}$ reported no mortalities and $13(15 \%)$ reoperations at a median follow-up of 7 years. They found no operative mortalities and 2 late mortalities. When comparing reoperations by quartiles of age, no difference was found between those in the younger group $(<0.75$ years) and those in other groups (ie, $0.75-1.5$ years, 1.5-3.75 years, and $>3.75$ years). As such, they recommended surgery before 2 years of age. ${ }^{4}$

A recent multicenter study by Buratto and colleagues ${ }^{9}$ found a tendency for increased reoperation $(P=.05)$ in 75 infants compared with 355 older children. After propensity score matching 52 pairs of patients, the 10-year freedom from reoperation in infants and children older than 1 year of age were $75.2 \%$ and $82.8 \%(P=.28)$, respectively. Nonetheless, it is unclear whether this is due to similar incidences or a decrease in power. They conclude that surgery should be deferred until later in childhood. ${ }^{9}$

The 40-year Mayo clinic experience ${ }^{25}$ and that reported by the group in Lyon ${ }^{10}$ seem to suggest a later age at operation may be beneficial. These are 2 of the series with the lowest reoperation rates $(8 \%$ and $7 \%$ at 10 years, respectively), yet the median age at repair in both was older than 5 years. Although reoperation rates were lower, arrhythmias were found to be more common with increasing age.

Our study, analyzing a large contemporary cohort with longer follow-up than most previously reported studies and a $72 \%$ complete follow-up, somewhat supports these findings. Even after controlling for potential confounders on the multivariable analysis, we found that those operated during infancy were more likely to require reoperation of all 


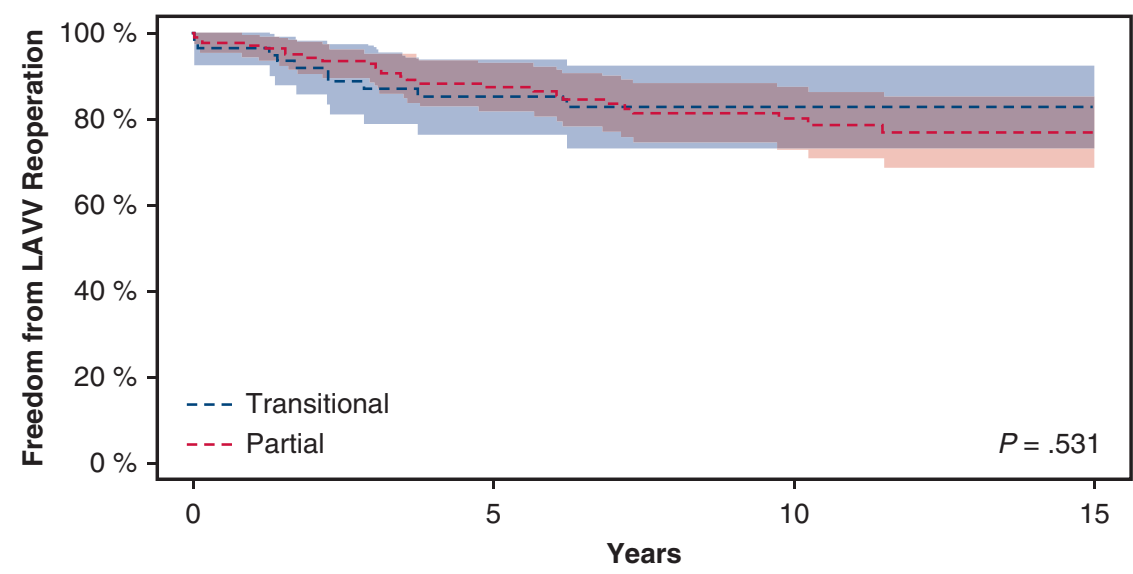

$\begin{array}{rcccc}\text { Number at risk } & & & & \\ \text { Transitional } & 88 & 44 & 61 & 7 \\ \text { Partial } & 177 & 104 & 61\end{array}$

A

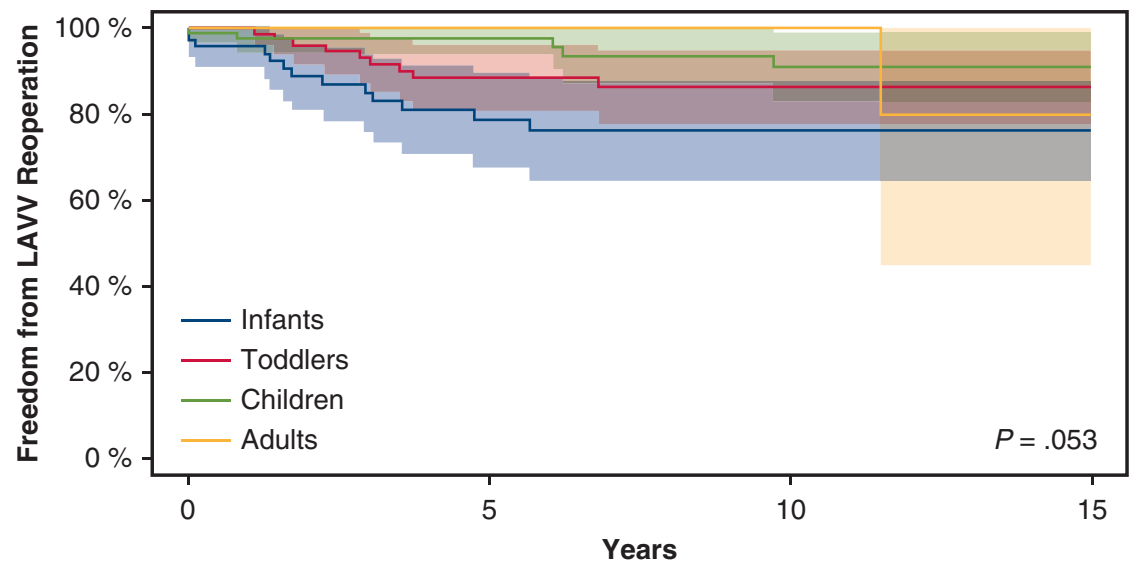

Number at risk

$\begin{array}{lllll}\text { Infants } & 73 & 35 & 20 & 4\end{array}$

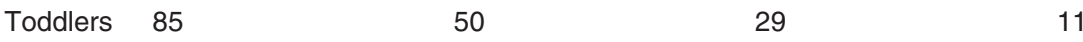

$\begin{array}{lllll}\text { Children } & 94 & 57 & 32 & 9\end{array}$

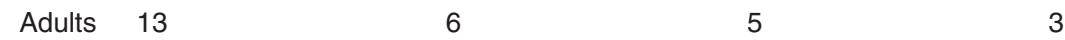

B

FIGURE 2. Freedom from LAVV reoperation by P/TAVSD (A) and age categories (B). LAVV, Left atrioventricular valve.

types. Repair during infancy is most likely a marker of more severe disease rather than the cause of reoperation. For asymptomatic patients or those who can be managed with low doses of medical treatment, a repair later in life may be reasonable. However, we believe that surgery should continue to be offered to infants with moderate or severe atrioventricular valve regurgitation or signs of heart failure.

Intuitively, an anomalous LAVV was associated to increased LAVV reoperation. The Boston group recently found an abnormal papillary muscle to be associated with a worse technical performance score, which in turn was strongly associated with late reoperation. ${ }^{6}$ We found that even though the repair was similarly effective, with postoperative LAVV regurgitation of $12 \%$ and $13.5 \%$ in the LAVV anomaly group and the entire cohort, respectively, an abnormal LAVV was an independent predictor of LAVV reoperation.

The incidence LVOT reoperation was $7 \%$ at 10 years, comparable to the $10 \%$ previously reported. ${ }^{8,26}$ Partial AVSD compared with transitional AVSD was a risk factor 


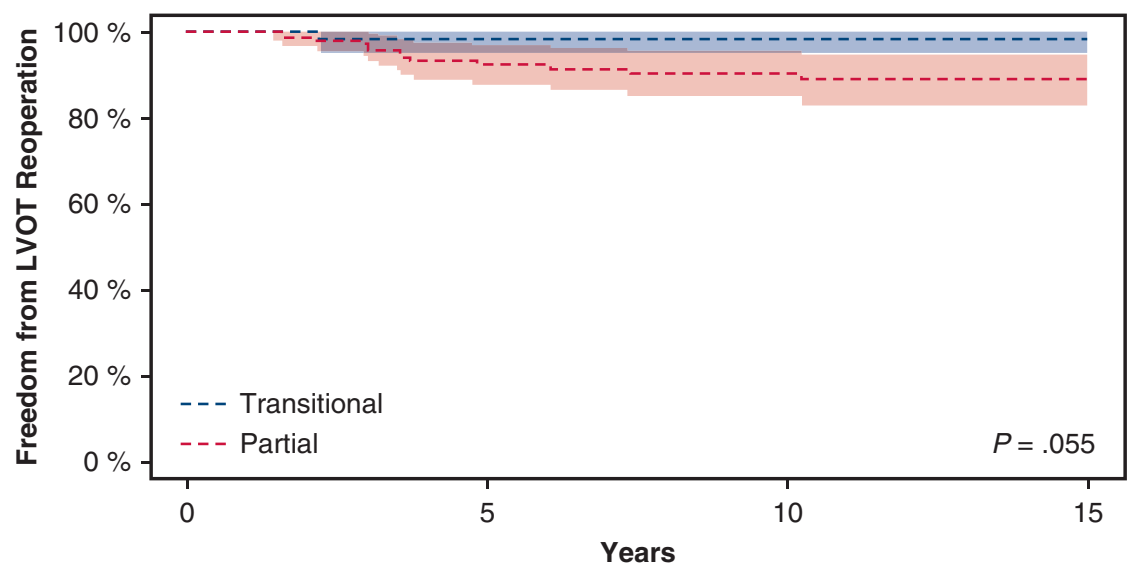

$\begin{array}{rcccc}\text { Number at risk } & & & & \\ \text { Transitional } & 88 & 49 & 67 & 10 \\ \text { Partial } & 177 & 108 & 26\end{array}$

A

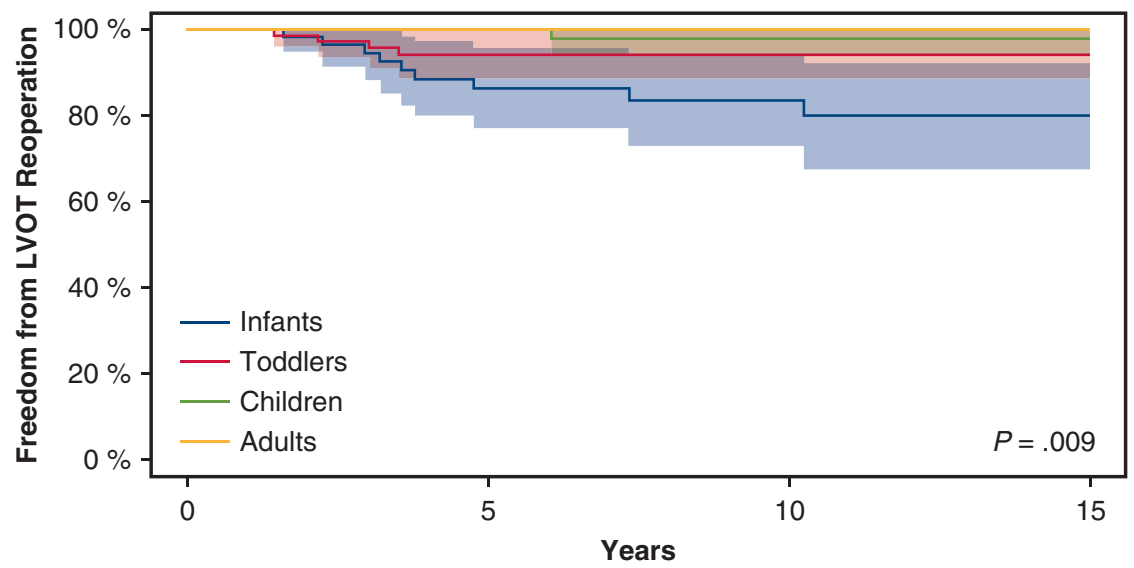

$\begin{array}{rcccc}\text { Number at risk } & & & & \\ \text { Infants } & 73 & 39 & 24 & 15 \\ \text { Toddlers } & 85 & 54 & 34 & 10 \\ \text { Children } & 94 & 58 & 5 & 3\end{array}$

B

FIGURE 3. Freedom from LVOT reoperation by P/TAVSD (A) and age categories (B). LVOT, Left ventricular outflow tract.

for higher incidence. The anatomy of the LVOT in AVSDs has been extensively described. The anomalous aortic root position, deficient muscular interventricular septum, short inlet with a long outlet septum, and increased encroaching by atrioventricular valve tissue on an already narrowed LVOT may predispose patients to increased LVOT obstruction. ${ }^{7,16,18,29,30}$ Contrary to other series, ${ }^{28,31}$ we did not find preoperative LVOT obstruction to be a significant predictor of LVOT reoperation after controlling for confounders. This observation may be due to low numbers or to a true lack of association.

\section{Study Limitations}

This study has several limitations, mainly related to its retrospective and single institutional nature. As such, it was not possible to assess the effect of some of the intricacies of atrioventricular valve morphology on the incidence of long-term reintervention. Echocardiographic variables were obtained from reports because imaging was not consistently available for the first 10 years of the study period. Some of the variables, such as the LAVV anomalies, were subjectively assessed and retrospectively collected. There were $28 \%$ (73/265) of patients 
lost to follow-up; this may be due to multiple socioeconomic factors such as patients moving or loss of insurance. Several limitations were present to ascertain mortality because of the current lack of a reliable easily accessible way of obtaining this information. Finally, given that our practice has been to wait until after infancy to proceed electively with the repair, an inherent selection bias is present.

\section{CONCLUSIONS}

Repair of P/TAVSD can be achieved with minimal mortality. Nonetheless, reoperation, especially LAVV reoperation, remains significant. The need for repair during infancy is associated with a higher risk of reoperation. This finding should be taken into account when counseling families.

\section{Webcast}

You can watch a Webcast of this AATS meeting presentation by going to: https://aats.blob.core.windows.net/ media/18May01/24ABC \% 202.Congenital $\% 20$ SS/S87\% 20-\%20Part\%201/S87_1_webcast_015800119.mp4.

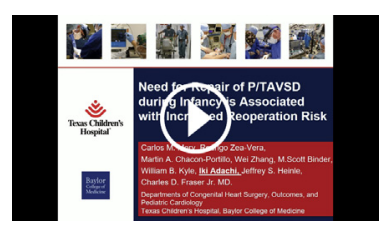

\section{Conflict of Interest Statement}

Authors have nothing to disclose with regard to commercial support.

The authors thank Phil Steffek for his expert support in producing and editing the video provided.

\section{References}

1. Jacobs JP, Mayer JE, Pasquali SK, Hill KD, Overman DM, St Louis JD, et al. The Society of Thoracic Surgeons congenital heart surgery database: 2018 update on outcomes and quality. Ann Thorac Surg. 2018;105:680-9.

2. Jacobs JP, Jacobs ML, Mavroudis C, Chai PJ, Tchervenkov CI, LacourGayet FG, et al. Atrioventricular septal defects: lessons learned about patterns of practice and outcomes from the congenital heart surgery database of the society of thoracic surgeons. World J Pediatr Congenit Heart Surg. 2010;1:68-77.

3. Hoohenkerk GJF, Bruggemans EF, Rijlaarsdam M, Schoof PH, Koolbergen DR, Hazekamp MG. More than 30 years' experience with surgical correction of atrioventricular septal defects. Ann Thorac Surg. 2010;90:1554-61.

4. Devlin PJ, Backer CL, Eltayeb O, Mongé MC, Hauck AL, Costello JM. Repair of partial atrioventricular septal defect: age and outcomes. Ann Thorac Surg. 2016; 102:170-7.

5. Bowman JL, Dearani JA, Burkhart HM, Goodloe AH, Phillips SD, Weaver AL, et al. Should repair of partial atrioventricular septal defect be delayed until later in childhood? Am J Cardiol. 2014;114:463-7.

6. Tishler B, Gauvreau K, Colan SD, Del Nido P, Nathan M. Technical performance score predicts partial/transitional atrioventricular septal defect outcomes. Ann Thorac Surg. 2018;105:1461-8.
7. Minich LL, Atz AM, Colan SD, Sleeper LA, Mital S, Jaggers J, et al. Partial and transitional atrioventricular septal defect outcomes. Ann Thorac Surg. 2010;89: 530-6.

8. Buratto E, McCrossan B, Galati JC, Bullock A, Kelly A, d'Udekem Y, et al. Repair of partial atrioventricular septal defect: a 37-year experience. Eur J Cardiothorac Surg. 2015;47:796-802.

9. Buratto E, Daley M, Ye XT, Radford DJ, Alphonso N, Brizard CP, et al. Propensity score matched analysis of partial atrioventricular septal defect repair in infancy. Heart Br Card Soc. 2018;104:1014-8.

10. Aubert S, Henaine R, Raisky O, Chavanis N, Robin J, Ecochard R, et al. Atypical forms of isolated partial atrioventricular septal defect increase the risk of initial valve replacement and reoperation. Eur J Cardiothorac Surg. 2005;28:223-8.

11. Chowdhury UK, Airan B, Malhotra A, Bisoi AK, Kalaivani M, Govindappa RM, et al. Specific issues after surgical repair of partial atrioventricular septal defect: actuarial survival, freedom from reoperation, fate of the left atrioventricular valve, prevalence of left ventricular outflow tract obstruction, and other events. J Thorac Cardiovasc Surg. 2009;137:548-55.e2.

12. Krupickova S, Morgan GJ, Cheang MH, Rigby ML, Franklin RC, Battista A, et al. Symptomatic partial and transitional atrioventricular septal defect repaired in infancy. Heart. 2018;104:1411-6.

13. Manning PB, Mayer JE, Sanders SP, Coleman EA, Jonas RA, Keane JF, et al. Unique features and prognosis of primum ASD presenting in the first year of life. Circulation. 1994;90(5 Pt 2):II30-5.

14. Chang CI, Becker AE. Surgical anatomy of left ventricular outflow tract obstruction in complete atrioventricular septal defect. A concept for operative repair. $J$ Thorac Cardiovasc Surg. 1987;94:897-903.

15. Shiokawa Y, Becker AE. The left ventricular outflow tract in atrioventricular septal defect revisited: surgical considerations regarding preservation of aortic valve integrity in the perspective of anatomic observations. J Thorac Cardiovasc Surg. 1997;114:586-93.

16. Adachi I, Ho SY, McCarthy KP, Uemura H. Ventricular scoop in atrioventricular septal defect: relevance to simplified single-patch method. Ann Thorac Surg. 2009;87:198-203.

17. Stulak JM, Burkhart HM, Dearani JA, Cetta F, Barnes RD, Connolly HM, et al. Reoperations after repair of partial atrioventricular septal defect: a 45-year single-center experience. Ann Thorac Surg. 2010;89:1352-9.

18. Piccoli GP, Ho SY, Wilkinson JL, Macartney FJ, Gerlis LM, Anderson RH. Leftsided obstructive lesions in atrioventricular septal defects: an anatomic study. $J$ Thorac Cardiovasc Surg. 1982;83:453-60.

19. Jacobs JP, Burke RP, Quintessenza JA, Mavroudis C. Congenital heart surgery nomenclature and database project: atrioventricular canal defect. Ann Thorac Surg. 2000;69(4 Suppl):S36-43.

20. Beaton AZ, Pike JI, Stallings C, Donofrio MT. Predictors of repair and outcome in prenatally diagnosed atrioventricular septal defects. J Am Soc Echocardiogr. 2013;26:208-16.

21. Zoghbi WA, Adams D, Bonow RO, Enriquez-Sarano M, Foster E, Grayburn PA, et al. Recommendations for noninvasive evaluation of native valvular regurgitation: a report from the American Society of Echocardiography developed in collaboration with the Society for Cardiovascular magnetic resonance. $J \mathrm{Am}$ Soc Echocardiogr. 2017;30:303-71.

22. Wilcox BR, Jones DR, Frantz EG, Brink LW, Henry GW, Mill MR, et al. Anatomically sound, simplified approach to repair of "complete" atrioventricular septal defect. Ann Thorac Surg. 1997;64:487-94.

23. Nicholson IA, Nunn GR, Sholler GF, Hawker RE, Cooper SG, Lau KC, et al. Simplified single patch technique for the repair of atrioventricular septal defect. J Thorac Cardiovasc Surg. 1999;118:642-6.

24. Lange R, Guenther T, Busch R, Hess J, Schreiber C. The presence of Down syndrome is not a risk factor in complete atrioventricular septal defect repair. $J$ Thorac Cardiovasc Surg. 2007;134:304-10.

25. El-Najdawi EK, Driscoll DJ, Puga FJ, Dearani JA, Spotts BE, Mahoney DW, et al. Operation for partial atrioventricular septal defect: a forty-year review. $J$ Thorac Cardiovasc Surg. 2000;119:880-90.

26. Najm HK, Williams WG, Chuaratanaphong S, Watzka SB, Coles JG, Freedom RM. Primum atrial septal defect in children: early results, risk factors, and freedom from reoperation. Ann Thorac Surg. 1998;66:829-35.

27. Van Arsdell GS, Williams WG, Boutin C, Trusler GA, Coles JG, Rebeyka IM, et al. Subaortic stenosis in the spectrum of atrioventricular septal defects. Solutions may be complex and palliative. J Thorac Cardiovasc Surg. 1995;110: 1534-42.

28. Abarbanell GL, Morrow G, Kelleman MS, Kanter KR, Border WL, Sachdeva R. Echocardiographic predictors of left ventricular outflow tract obstruction 
following repair of atrioventricular septal defect. Congenit Heart Dis. May 12, 2016 [Epub ahead of print].

29. Overman DM. Reoperation for left ventricular outflow tract obstruction after repair of atrioventricular septal. Semin Thorac Cardiovasc Surg Pediatr Card Surg Аппи. 2014;17:43-7.

30. Ebels T, Ho SY, Anderson RH, Meijboom EJ, Eijgelaar A. The surgical anatomy of the left ventricular outflow tract in atrioventricular septal defect. Ann Thorac Surg. 1986;41:483-8.

31. Lim DS, Ensing GJ, Ludomirsky A, Mooradian SJ, Rocchini AP. Echocardiographic predictors for the development of subaortic stenosis after repair of atrioventricular septal defect. Am J Cardiol. 2003;91:900-3.

Key Words: atrioventricular septal defect, atrioventricular canal, partial atrioventricular septal defect, partial atrioventricular canal, transitional atrioventricular septal defect, transitional atrioventricular canal, primum atrial septal defect

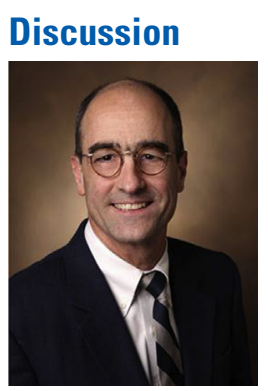

Dr David P. Bichell (Nashville, Tenn). You and your co-authors are to be commended. You have presented one of the larger studies of partial and transitional atrioventricular (AV) canal and are helping to contribute to the framework of thinking about how and when to operate on this largely asymptomatic group. I have a few questions, and you may have partially addressed this in discussing your limitations, but I would be interested in your thoughts a little further.

Your stated goal in this study was to determine risk factors for reoperation, largely for left $\mathrm{AV}$ valve regurgitation, and as that relates to age at repair. You found that there was basically an inverse relationship between age at repair and the incidence of reoperation for left AV valve regurgitation or other things, and each successive age group enjoyed a successively lower reintervention rate, suggesting that maybe a late repair is the optimal target. Your institutional preference is to operate after 3 . Did the ones who were operated on as neonates or infants have a reason to have gone to repair before age 3 ? Among your indications for early operation is left AV valve insufficiency. So is it circular reasoning to consciously assign those with important left $\mathrm{AV}$ valve regurgitation to the infant group and then to conclude that the infant group is more at risk as if it were inherent? I will ask for your comments on that, and then I have a second question.

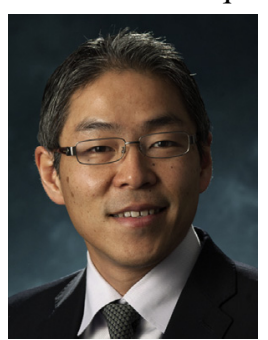

Dr Iki Adachi (Houston, Tex). Thank you.

Dr Bichell. Actually, that's a question we had and why we organized the study this way using the multivariate analysis to see the actual independent impact on age. On the basis of this assessment, we can say that the age infancy was an independent risk for the future reoperation, although, as I mentioned, it's also possible we missed some of the important confounders.

Dr Bichell. I have another related question. You found that the incidence of important valvular regurgitation was pretty evenly distributed across the age groups, approximately $33 \%$ in the infant, 1 to 3 , and after 3 groups. Do your data track the emergence of left AV valve regurgitation? Stated another way, if there's 33\% moderate to severe AV valve regurgitation in the 3- to 5-year-olds, did they always have that, and if so, could that amount of $\mathrm{AV}$ valve regurgitation in the older kids have been prevented if they had been operated on earlier? So the real question is, do you have a timeline of the evolution of AV valve regurgitation in these groups from the data that you examined?

Dr Adachi. I don't think we have the answer for that question, particularly because sometimes some patients are referred to us at a late age with already significant AV valve regurgitation. Probably, to answer your question, we need to focus on the patients who we are following from the beginning.

In this study, there were 90 patients who had moderate or severe $\mathrm{AV}$ valve regurgitation at the time of operation, and of 90, approximately two-thirds of patients already had moderate or severe $\mathrm{AV}$ valve regurgitation at the initial echocardiogram in our institution. So we can't really tell the progression in these patients' operation. But the remaining 30 patients initially had moderate or less AV valve regurgitation, and then this $\mathrm{AV}$ valve regurgitation just progressed to reach the point where we considered operation. So there was a subset of patients who had progression of $\mathrm{AV}$ valve regurgitation.

And regarding your question, it could have been possible that we prevented this progression of $\mathrm{AV}$ valve regurgitation by earlier intervention, although we also did a separate analysis whether the presence of severe or moderate to severe AV valve regurgitation could be a risk factor for future AV valve repair, and actually the answer was no. So the infancy was an independent risk for this future operation, but the presence of significant $\mathrm{AV}$ valve regurgitation at the time of operation was not an independent risk for the future AV valve operation. So on the basis of these data, I don't know if we can justify earlier intervention just to prevent the progression of $\mathrm{AV}$ valve regurgitation.

Dr Bichell. A very nice presentation.

Dr Christian Pizzaro. Iki, that was a nice presentation. I noticed that the incidence of a second run of bypass for the transitional canal was about double of the partial canal. Could you explain a little about the nature of that?

Dr Adachi. The reason why the patients needed a second bypass run, most of them were actually because of the residual VSD leak, not necessarily because of the $\mathrm{AV}$ valve issue in this series. 


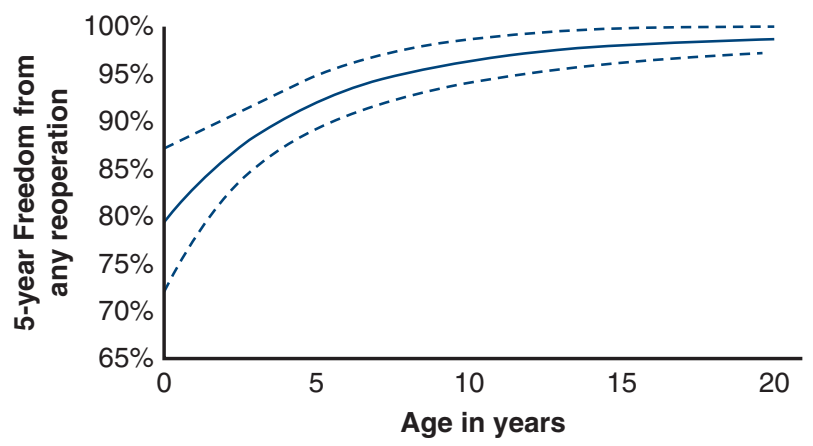

FIGURE E1. Freedom from reoperation at 5 years by age at repair for a patient with no CHF, no genetic syndrome, no heterotaxy, and no LAVV anomaly.
TABLE E1. Multivariable analysis for any reoperation, left atrioventricular valve reoperation, and left ventricular outflow tract reoperation using age and age $^{2}$ instead of age categories

\begin{tabular}{|c|c|c|}
\hline Covariate & HR $(95 \%$ CI $)$ & $P$ value \\
\hline \multicolumn{3}{|l|}{ Any reoperation } \\
\hline Age (y) & $0.80(0.66-0.97)$ & .025 \\
\hline $\operatorname{Age}(y)^{2}$ & $1.004(1.000-1.007)$ & .023 \\
\hline No genetic syndrome & Reference & \\
\hline Trisomy $21 *$ & $0.22(0.07-0.73)$ & .014 \\
\hline Other genetic syndromes & $1.68(0.49-5.73)$ & .405 \\
\hline Heterotaxy* & $3.59(1.32-9.72)$ & .012 \\
\hline Congestive heart failure & $1.10(0.53-2.30)$ & .793 \\
\hline LAVV anomaly & $1.71(0.83-3.52)$ & .145 \\
\hline \multicolumn{3}{|l|}{ LAVV reoperation } \\
\hline Age (y) & $0.80(0.64-1.01)$ & .056 \\
\hline Age $(y)^{2}$ & $1.004(1.000-1.008)$ & .043 \\
\hline No genetic syndrome & Reference & \\
\hline Trisomy $21^{*}$ & $0.19(0.04-0.79)$ & .024 \\
\hline Other genetic syndromes & $1.38(0.32-6.07)$ & .668 \\
\hline Congestive heart failure & $1.49(0.64-3.39)$ & .357 \\
\hline LAVV anomaly* & $2.23(0.99-4.97)$ & .051 \\
\hline \multicolumn{3}{|l|}{ LVOT reoperation } \\
\hline Age (y) & $0.51(0.30-0.87)$ & .013 \\
\hline $\operatorname{Age}(y)^{2}$ & $1.01(0.99-1.02)$ & .138 \\
\hline Transitional AVSD & Reference & \\
\hline Partial AVSD* & $8.19(1.06-63.39)$ & .044 \\
\hline $\begin{array}{l}\text { Preoperative significant } \\
\text { LVOT obstruction }\end{array}$ & $4.27(0.54-34.00)$ & .171 \\
\hline
\end{tabular}


TABLE E2. Univariate analysis for any reoperation

\begin{tabular}{|c|c|c|c|c|}
\hline & \multirow[b]{2}{*}{$\mathbf{N}(\%)$} & \multicolumn{3}{|c|}{ Freedom from any reoperation $\%(95 \% \mathrm{CI})$} \\
\hline & & $5 \mathbf{y}$ & $10 \mathrm{y}$ & $P^{*}$ \\
\hline Infant & $73(28)$ & $73.5(62.6-86.2)$ & $65.6(53.5-80.6)$ & .003 \\
\hline Toddler & $85(32)$ & $87.1(79.5-95.3)$ & $82.8(73.9-92.8)$ & \\
\hline Children & $94(35)$ & $95.3(90.9-99.9)$ & $88.8(80.8-97.5)$ & \\
\hline Adult & $13(5)$ & $100(100-100)$ & $100(100-100)$ & \\
\hline Partial AVSD & $177(67)$ & $87.3(82.0-93.0)$ & $80.1(73.1-87.7)$ & .833 \\
\hline Transitional AVSD & $88(33)$ & $85.2(77.0-94.2)$ & $82.9(73.9-92.9)$ & \\
\hline $\begin{array}{l}\text { Genetic syndrome } \\
\text { None } \\
\text { Trisomy } 21 \\
\text { Others }\end{array}$ & $\begin{array}{r}175(66) \\
76(29) \\
14(5)\end{array}$ & $\begin{array}{l}83.3(77.2-89.8) \\
96.3(91.5-100) \\
78.6(59.8-100)\end{array}$ & $\begin{array}{l}75.8(68.4-84.1) \\
94.0(87.5-100) \\
78.6(59.8-100)\end{array}$ & .012 \\
\hline $\begin{array}{l}\text { Heterotaxy } \\
\text { No } \\
\text { Yes }\end{array}$ & $\begin{array}{c}256(97) \\
9(3)\end{array}$ & $\begin{array}{l}87.4(82.9-92.2) \\
64.8(39.3-100)\end{array}$ & $\begin{array}{l}82.8(77.3-88.7) \\
32.4(10.8-97.4)\end{array}$ & $<.001$ \\
\hline $\begin{array}{l}\text { Second CPB run } \\
\text { No } \\
\text { Yes }\end{array}$ & $\begin{array}{c}254(96) \\
11(4)\end{array}$ & $\begin{array}{c}86.2(81.6-91.2) \\
100(100-100)\end{array}$ & $\begin{array}{c}80.2(74.4-86.4) \\
100(100-100)\end{array}$ & .271 \\
\hline $\begin{array}{l}\text { CHF } \\
\text { No } \\
\text { Yes }\end{array}$ & $\begin{array}{l}163(62) \\
102(38)\end{array}$ & $\begin{array}{l}89.9(84.7-95.3) \\
82.4(74.7-90.9)\end{array}$ & $\begin{array}{l}86.8(80.4-93.7) \\
73.5(64.2-84.1)\end{array}$ & .052 \\
\hline $\begin{array}{l}\text { LAVV anomaly } \\
\text { No } \\
\text { Yes }\end{array}$ & $\begin{array}{r}223(85) \\
42(15)\end{array}$ & $\begin{array}{l}88.7(84.1-93.5) \\
77.2(64.4-92.5)\end{array}$ & $\begin{array}{l}84.2(78.4-90.3) \\
65.2(50.1-84.9)\end{array}$ & .032 \\
\hline $\begin{array}{l}\text { Preoperative moderate or more LAVV regurgitation } \\
\text { No } \\
\text { Yes }\end{array}$ & $\begin{array}{r}175(66) \\
90(34)\end{array}$ & $\begin{array}{l}87.9(82.5-93.7) \\
84.3(76.5-93.0)\end{array}$ & $\begin{array}{l}83.3(76.7-90.5) \\
76.5(66.6-87.8)\end{array}$ & .257 \\
\hline $\begin{array}{l}\text { Preoperative significant LVOTO } \\
\text { No } \\
\text { Yes }\end{array}$ & $\begin{array}{c}261(98) \\
4(2)\end{array}$ & $\begin{array}{l}87.0(82.4-91.7) \\
66.7(30.0-100)\end{array}$ & $\begin{array}{l}81.1(75.4-87.2) \\
66.7(30.0-100)\end{array}$ & .367 \\
\hline
\end{tabular}

$C I$, Confidence interval; $A V S D$, atrioventricular septal defect; $C P B$, cardiopulmonary bypass; $C H F$, congestive heart failure; $L A V V$, left atrioventricular valve; $L V O T O$, left ventricular outflow tract obstruction. ${ }^{*} P$ value by $\log$-rank test. 
TABLE E3. Univariate analysis for left atrioventricular valve reoperation

\begin{tabular}{|c|c|c|c|c|}
\hline & \multirow[b]{2}{*}{$\mathbf{N}(\%)$} & \multicolumn{3}{|c|}{ Freedom from LAVV reoperation $\%(95 \%$ CI $)$} \\
\hline & & $5 y$ & $10 \mathrm{y}$ & $\boldsymbol{P}^{*}$ \\
\hline Infant & $73(28)$ & $78.7(68.5-90.4)$ & $76.2(65.4-88.7)$ & .054 \\
\hline Toddler & $85(32)$ & $88.4(81.1-96.3)$ & $86.2(78.1-95.2)$ & \\
\hline Children & $94(35)$ & $97.5(94.1-100)$ & $90.9(83.2-99.2)$ & \\
\hline Adult & $13(5)$ & $100(100-100)$ & $100(100-100)$ & \\
\hline Partial AVSD & $177(67)$ & $90.6(85.9-95.7)$ & $86.4(80.4-92.8)$ & .534 \\
\hline Transitional AVSD & $88(33)$ & $86.2(78.1-95.1)$ & $83.9(75.0-93.8)$ & \\
\hline $\begin{array}{l}\text { Genetic syndrome } \\
\text { None } \\
\text { Trisomy } 21 \\
\text { Others }\end{array}$ & $\begin{array}{c}175(66) \\
76(29) \\
14(5)\end{array}$ & $\begin{array}{l}85.8(80.1-92.0) \\
98.2(94.8-100) \\
85.7(69.2-100)\end{array}$ & $\begin{array}{l}81.4(74.7-88.8) \\
95.9(90.4-100) \\
85.7(69.2-100)\end{array}$ & .034 \\
\hline $\begin{array}{l}\text { Heterotaxy } \\
\text { No } \\
\text { Yes }\end{array}$ & $\begin{array}{c}256(97) \\
9(3)\end{array}$ & $\begin{array}{l}89.4(85.2-93.8) \\
83.3(58.3-100)\end{array}$ & $\begin{array}{l}85.6(80.4-91.0) \\
83.3(58.3-100)\end{array}$ & .819 \\
\hline $\begin{array}{l}\text { Second CPB run } \\
\text { No } \\
\text { Yes }\end{array}$ & $\begin{array}{c}254(96) \\
11(4)\end{array}$ & $\begin{array}{c}88.9(84.7-93.5) \\
100(100-100)\end{array}$ & $\begin{array}{c}85.1(79.9-90.7) \\
100(100-100)\end{array}$ & .521 \\
\hline $\begin{array}{l}\text { CHF } \\
\text { No } \\
\text { Yes }\end{array}$ & $\begin{array}{l}163(62) \\
102(38)\end{array}$ & $\begin{array}{l}93.6(89.4-98.1) \\
83.6(76.1-91.9)\end{array}$ & $\begin{array}{l}90.5(84.6-96.7) \\
79.3(70.9-88.7)\end{array}$ & .049 \\
\hline $\begin{array}{l}\text { LAVV anomaly } \\
\text { No } \\
\text { Yes }\end{array}$ & $\begin{array}{r}223(85) \\
42(15)\end{array}$ & $\begin{array}{l}91.9(87.9-96.1) \\
77.2(64.4-92.5)\end{array}$ & $\begin{array}{l}89.1(84.1-94.3) \\
69.3(54.7-87.7)\end{array}$ & .005 \\
\hline $\begin{array}{l}\text { Preoperative moderate or more LAVV } \\
\text { regurgitation } \\
\text { No } \\
\text { Yes }\end{array}$ & $\begin{array}{r}175(66) \\
90(34)\end{array}$ & $\begin{array}{l}90.9(86.0-96.0) \\
86.4(78.8-94.7)\end{array}$ & $\begin{array}{l}87.5(81.6-93.8) \\
82.1(73.2-92.2)\end{array}$ & .438 \\
\hline $\begin{array}{l}\text { Preoperative significant LVOTO } \\
\text { No } \\
\text { Yes }\end{array}$ & $\begin{array}{c}261(98) \\
4(2)\end{array}$ & $\begin{array}{c}89.1(84.9-93.6) \\
100(100-100)\end{array}$ & $\begin{array}{c}85.4(80.3-90.8) \\
100(100-100)\end{array}$ & .573 \\
\hline
\end{tabular}


TABLE E4. Univariate analysis for left ventricular outflow tract reoperation

\begin{tabular}{|c|c|c|c|c|}
\hline & \multirow[b]{2}{*}{$\mathbf{N}(\%)$} & \multicolumn{3}{|c|}{ Freedom from LVOT reoperation $\%(95 \%$ CI $)$} \\
\hline & & $5 \mathbf{y}$ & $10 \mathrm{y}$ & $\boldsymbol{P} *$ \\
\hline Infant & $73(28)$ & $86.2(77.1-96.3)$ & $83.5(73.5-94.8)$ & .009 \\
\hline Toddler & $85(32)$ & $94.2(88.9-99.9)$ & $94.2(88.9-99.9)$ & \\
\hline Children & $94(35)$ & $100(100-100)$ & $98.0(94.2-100)$ & \\
\hline Adult & $13(5)$ & $100(100-100)$ & $100(100-100)$ & \\
\hline Partial AVSD & $177(67)$ & $92.4(88.0-97.1)$ & $90.4(85.4-95.8)$ & .055 \\
\hline Transitional AVSD & $88(33)$ & $98.3(95.1-100)$ & $98.3(95.1-100)$ & \\
\hline $\begin{array}{l}\text { Genetic syndrome } \\
\text { None } \\
\text { Trisomy } 21 \\
\text { Others }\end{array}$ & $\begin{array}{c}175(66) \\
76(29) \\
14(5)\end{array}$ & $\begin{array}{c}92.2(87.7-97.0) \\
98.1(94.4-100) \\
100(100-100)\end{array}$ & $\begin{array}{c}90.2(85.0-95.7) \\
98.1(94.4-100) \\
100(100-100)\end{array}$ & .119 \\
\hline $\begin{array}{l}\text { Heterotaxy } \\
\text { No } \\
\text { Yes }\end{array}$ & $\begin{array}{c}256(97) \\
9(3)\end{array}$ & $\begin{array}{c}94.0(90.7-97.5) \\
100(100-100)\end{array}$ & $\begin{array}{c}92.6(88.7-96.6) \\
100(100-100)\end{array}$ & .497 \\
\hline $\begin{array}{l}\text { Second CPB run } \\
\text { No } \\
\text { Yes }\end{array}$ & $\begin{array}{c}254(96) \\
11(4)\end{array}$ & $\begin{array}{c}88.9(84.6-93.4) \\
100(100-100)\end{array}$ & $\begin{array}{c}85.1(79.9-90.6) \\
100(100-100)\end{array}$ & .491 \\
\hline $\begin{array}{l}\text { CHF } \\
\text { No } \\
\text { Yes }\end{array}$ & $\begin{array}{l}163(62) \\
102(38)\end{array}$ & $\begin{array}{l}96.3(92.8-99.9) \\
91.5(85.7-97.7)\end{array}$ & $\begin{array}{l}95.0(90.8-99.4) \\
90.0(83.7-96.9)\end{array}$ & .138 \\
\hline $\begin{array}{l}\text { LAVV anomaly } \\
\text { No } \\
\text { Yes }\end{array}$ & $\begin{array}{r}223(85) \\
42(15)\end{array}$ & $\begin{array}{l}95.5(92.4-98.8) \\
88.0(77.7-99.8)\end{array}$ & $\begin{array}{l}93.8(90.0-97.9) \\
88.0(77.7-99.8)\end{array}$ & .229 \\
\hline $\begin{array}{l}\text { Preoperative moderate or more LAVV } \\
\text { regurgitation } \\
\text { No } \\
\text { Yes }\end{array}$ & $\begin{array}{r}175(66) \\
90(34)\end{array}$ & $\begin{array}{l}92.6(88.1-97.4) \\
97.1(93.2-100)\end{array}$ & $\begin{array}{l}90.3(84.9-96.0) \\
97.1(93.2-100)\end{array}$ & .213 \\
\hline $\begin{array}{l}\text { Preoperative significant LVOTO } \\
\text { No } \\
\text { Yes }\end{array}$ & $\begin{array}{c}261(98) \\
4(2)\end{array}$ & $\begin{array}{l}94.7(91.5-97.9) \\
66.7(30.0-100)\end{array}$ & $\begin{array}{l}93.2(89.6-97.0) \\
66.7(30.0-100)\end{array}$ & .011 \\
\hline
\end{tabular}

